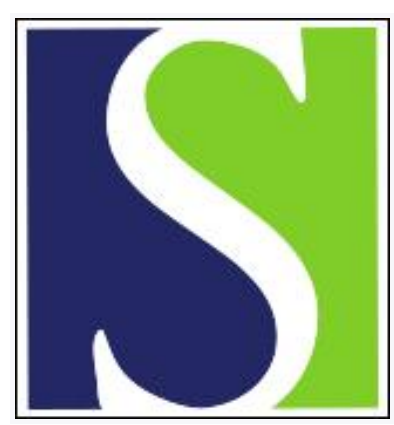

Scand J Work Environ Health 1996;22(5):353-359

https://doi.org/10.5271/sjweh.153

Issue date: Oct 1996

Effects of long workhours on life-style, stress and quality of life among intermediate Japanese managers

by Maruyama S, Morimoto K

The following articles refer to this text: 2003;29(3):171-188;

2006;32(4):318-327; 2008;34(5):356-363;

Key terms: health practice; overtime work; primary prevention; satisfaction

This article in PubMed: www.ncbi.nlm.nih.gov/pubmed/8923608

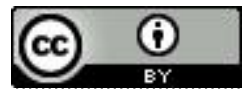




\title{
Effects of long workhours on life-style, stress and quality of life among intermediate Japanese managers
}

\author{
by Soichiro Maruyama, MD, ${ }^{1}$ Kanehisa Morimoto, DrMedSC ${ }^{1}$
}

\begin{abstract}
Maruyama S, Morimoto K. Effects of long workhours on life-style, stress and quality of life among intermediate Japanese managers. Scand J Work Environ Health 1996;22:353-9.
\end{abstract}

\begin{abstract}
Objectives In accordance with international coordination of labor conditions a Japanese campaign advocating less work finally got under way recently in the form of work-reducing policies of the government to prevent occupational and stress-related diseases. However, long workhours among intermediate managers, who are key persons in most organizations in Japanese industry, are still considered to be prevalent. This study was conducted to examine the workhours of intermediate managers and clarify the effects of long workhours on the life-style, subjective stress, and subjective quality of life among them.

Methods Questionnaires were administered concerning workhours, life-styles, subjective stress, and subjective quality of life to 3870 heads of a division or a section and 2666 foremen in 110 firms in Japan.

Results The prevalence of $\geq 10$ workhours was $69.7 \%$ for the divisional or sectional heads and $53.2 \%$ for the foremen. Long workhours had significant effects on the managers' life-style, such as sleeping pattern and regularity of daily life and meals. The divisional or sectional managers with long workhours perceived higher stress [odds ratio (OR) $2.51,95 \%$ confidence interval $(95 \% \mathrm{CI}) 2.17-2.90$ ] and lower quality of life (OR 1.17 , $95 \%$ CI $1.02-1.36)$ than those who worked relatively short hours. The foremen with long workhours perceived higher stress (OR 2.35, 95\% CI 2.01-2.75) and lower quality of life (OR 1.26, 95\% Cl 1.08-1.46) than those who worked relatively short hours.
\end{abstract}

Conclusions Long workhours may be associated with poorer life-style, higher stress, and lower quality of life among managers at the intermediate level.

Key terms health practice, overtime work, primary prevention, satisfaction.

Recently, long workhours in Japan have often been criticized as a cause of occupational diseases, including "Karoshi", meaning death from fatigue (1), and also stress-related diseases. Shorter workhours have been regarded as an urgent national objective, not only to help prevent work-related diseases and promote health, but also to help improve the quality of life (2-4).

In Japan, however, cuts in workhours without sufficient improvements in productivity are associated with the risk of an increase in voluntary unpaid overtime work and work at home.

Today, with the slow economic growth rate and chronic depression after the collapse of the so-called "bubble economy," adjustment of the work force by prolonging or shortening workhours has exceeded the capacity of individual firms, and the traditional Japanese style of employment, characterized by life-long employment and a seniority system of payment, has become difficult to maintain in some enterprises. As a result, some companies resort to labor reduction primarily in the middle-aged and aged intermediate management class as part of restructuring. This practice has raised a social issue. In such a difficult occupational environment, the middle-aged and aged management class, who used to feel relatively comfortable about life (3), is considered to receive little benefit from the work reduction campaign.

There is much evidence linking workhours and health status. Harrington (5) has pointed out that most previous investigations are still rooted in studies of relationships between shift work, night work, and health. Working long hours has also been shown to be related to coronary heart disease $(1,6,7)$, stress $(8,9)$, mental health $(10)$, indefinite complaints (11), fatigue (12), dissatisfaction with work (13), and depression (14).

To help prevent chronic diseases, which account for the predominant part of health problems in advanced countries, the evaluation of life-style in the stage of primary prevention is considered important $(15,16)$. There-

1 Department of Hygiene and Preventive Medicine, School of Medicine, Osaka University, Osaka, Japan.

Reprint requests to: Professor Kanehisa Morimoto, Department of Hygiene and Preventive Medicine, School of Medicine, Osaka University, Yamada-oka, Suita, Osaka 565, Japan. 
fore, the effects of long workhours on the life-style of a person should be clarified. Moreover, if working long hours increases workers' stress and deteriorates their quality of life, working less is an important health care problem of the entire organization. In this study, workhours were examined among persons in intermediate management. These people are key persons in industrial organizations. The relationships of workhours with life-style, subjective stress level, and subjective quality of life were also evaluated.

\section{Subjects and methods}

\section{Subjects}

The subjects were selected from 20140 intermediate managers at 110 businesses that cooperated in this investigation among the 212 firms that were registered at the Foundation for Promotion of Industrial Medicine, an affiliated organization of the Ministry of Labor, as having at least 500 regular employees and a full-time industrial physician. The subjects were selected from every other position of the hierarchical order adopted by each firm. Thus a questionnaire was distributed to 1244 divisional heads, 3922 sectional heads, and 3738 foremen. The questionnaire was anonymously completed and returned by mail directly to the Foundation for Promotion of Industrial Medicine. It was returned by 6895 subjects (6827 men, 6 women, with 62 not answering) for a response rate of $76.6 \%$. The questionnaire survey was performed between May and July 1990.

All items of the questionnaire were completed by 3870 divisional or sectional heads and 2666 foremen, who were all males; these intermediate managers comprised the total in the present study. The mean ages were 47.01 (SD 5.01) and 46.31 (SD 5.71) years for the divisional or sectional heads and foremen, respectively. Of these managers, $87.1 \%$ belonged to firms listed on the stock exchange, $3.8 \%$ were in electricity, gas, and heat supply industries, $6.3 \%$ in finance and insurance industries, $1.1 \%$ in transport and communication industries, $0.1 \%$ in the construction industry, $86.0 \%$ in the manufacturing industry, $1.0 \%$ in the service industry, and $1.7 \%$ in other industries. By type of division, $48.7 \%$ of subjects were in manufacturing and $51.3 \%$ were in other divisions.

\section{Investigated items}

The questionnaire was completed by each subject. Their height and weight were recorded, and responses to other questions were selected from suggested possibilities.

Workhours. The questionnaire asked about the usual worktime per day on weekdays. The original form of the question was: "How long was the recent mean actual workhours per day." The subjects selected from "7 hours or less," "8 hours," "9 hours," "10 hours," and "11 hours or longer." A 1-h interval was adopted for the central three categories.

Life-style (habits in everyday life). Significant relationships between life-style and physical and mental health have been established by Breslow, Morimoto and their colleagues $(15,16,19-22)$. We have also previously shown that the frequency of chromosome aberrations (SCE) is lower (19) and the natural killer cell activity is higher (20) as the desirable features of life-style increase. In other studies $(21,22)$, life-style was significantly related to both mental and physical heath. In this study, we evaluated smoking, drinking, sleep, exercise, degree of obesity, breakfast, eating between meals, salt intake, intake of beverages of taste, nutritional balance, hobbies, degree of business, regularity of daily life, regularity of meals, and physical condition during the last six months, including the seven life-style items recommended by Berkman \& Breslow (15).

Subjective stress level. We compiled overall indices on subjective stress. The self-rating of stress, which was made on a single-item response, was scored on a threepoint scale. The subjective stress level was selected from "high," "average," and "low" and was scored by giving 3,2 , and 1 points to the respective answers. Validity and reliability were analyzed with respect to natural killer cell activity (20), primary symptoms (21), and general health questionnaire data (22). From these analyses, we found that the subjects with a higher subjective stress level (level 3) tended to have less natural killer cell activity, more symptoms and poorer mental health than the low-stress group (level 1 or 2). Thus subjects for whom the subjective stress score was 3 were regarded as the high-stress group.

Subjective quality of life. The questions on the seven items concerning subjective quality of life were derived from European and American literature with modifications by Japanese concepts about the quality of life (23). They covered occupational and nonoccupational aspects of quality of life, such as home and leisure time, namely, "perception of good work," "human relations at the workplace," "physical environment of the workplace," "income," "family life," "use of leisure," and "hopes for the future." Each question was answered as "very satisfactory," "moderately satisfactory" (1 point was given to both answers), "fair," or "unsatisfactory" (a rating of 0 was given to these answers). The total score of the seven items ( $0-7$ points) was regarded as an index of subjective quality of life. The alpha coefficient of internal reliability was 0.67 . Subjects for whom the score of subjec- 
tive quality of life was 3 or less were regarded as the low quality-of-life group because the mean quality of life score of the total subjects was 3.77 .

\section{Analytical methods}

The subjects were divided into the age groups of $\leq 44$ years, $45-49$ years, and $\geq 50$ years separately for the divisional or sectional heads and the foremen, and the following analyses were performed. To determine the distribution of workhours and the relationship between workhours and life-style, the subjects were divided into those who worked $\geq 10$ hours (long workhour group) and those who worked for $\leq 9$ hours (short workhour group). Then, the percentage of individuals with an undesirable life-style was calculated for each group at each age level and with all the age levels combined. Workhours were considered to be related directly or indirectly via life-style to subjective stress and subjective quality of life. Therefore, the relationship between workhours and subjective stress and the relationship between workhours and subjective quality of life were also evaluated. The theoretical model of this study is shown in figure 1 . The indirect effects of long workhours on health through life-style was not analyzed.

For the statistical analysis the chi-square test was performed for the distribution of workhours and the relationship between workhours and life-style. A oneway analysis of variance was performed to determine the relationship between workhours and subjective stress and the relationship between workhours and quality of life, and the odds ratios of the appearance of the high-stress group and low-quality of life group were calculated with the effects of multiple factors (age, number of years in managerial positions, number of subordinates, and type of division) taken into consideration.

\section{Results}

\section{Workhours}

Figure 2 shows the distribution of the workhours of the divisional or sectional heads and foremen. The divisional or sectional heads tended to work longer hours than the foremen.

\section{Relationship between workhours and life-style}

Table 1 includes only the items which showed a statistically significant difference between workhours and lifestyle in all the age groups separately for the divisional or sectional heads and the foremen. Other items have been described in the text. The cut-off points for a high-risk life-style were as follows: cigarette smoking (smoker), alcohol consumption (every day), sleeping pattern ( $6 \mathrm{~h}$ or less per day), physical exercise (once or less per day), obesity ( $\geq 10 \%$ underweight and $\geq 10 \%$ overweight), eating breakfast (not every day), eating between meals (yes), salt take (poor control), black tea or coffee (5 or more cups), nutritional balance (unbalanced), enjoying hobbies (no), feeling busy (yes), regularity of daily life (irregular), regularity of meals (irregular), and physical condition during the last six months (worse).

Smoking and drinking. Among the foremen, the percentage of smokers or frequent drinkers was higher in the long workhour group at all the age levels, and significant differences were observed between workhours and smoking at the age level of $45-49$ years and for all the age levels combined and between workhours and drinking for the age levels of $45-49$ years, $\geq 50$ years, and all age levels combined.

Sleep. The sleeping time was $6 \mathrm{~h}$ or less more frequently in the long workhour group at all the age levels. Significant differences were observed between the workhours and sleeping hours for the divisional or sectional heads in each age level and for all the age levels combined and for the foremen in the age levels of $\leq 44$ years, $45-49$ years, and all the age levels combined.

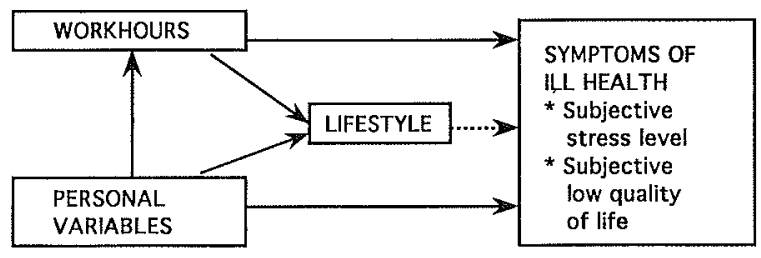

Figure 1. Theoretical model of the relationship between workhours and outcomes. The direct links between the variables of this study (ie, the solid lines in the figure) were analyzed.

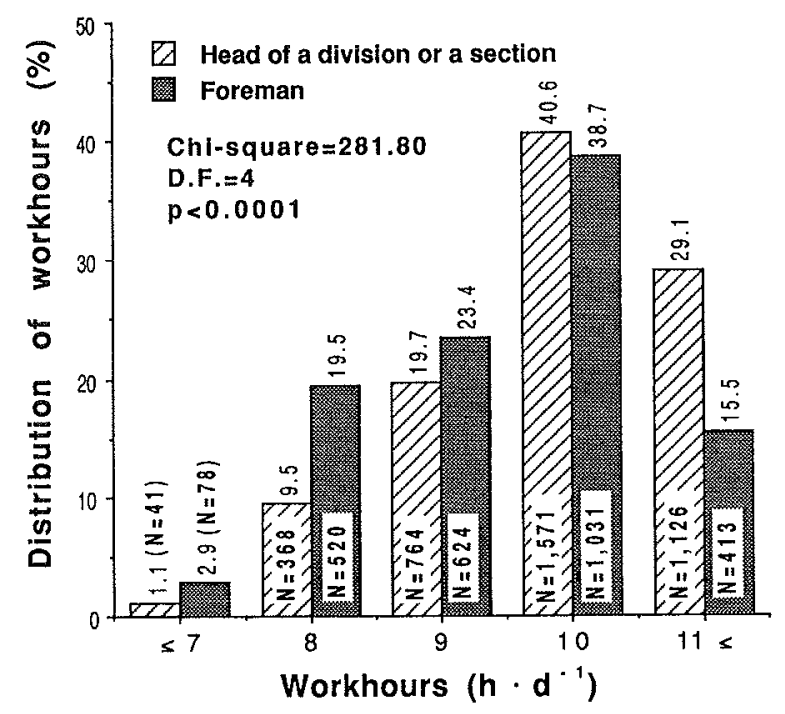

Figure 2. Distribution of the workhours of 3870 heads of a division or section and 2666 foremen. 
Table 1. Prevalence of high-risk life-style factors in the two workhour groups of the heads of a division or a section $(\mathrm{N}=3870)$ and the foremen $(N=2666)$ according to age group.

\begin{tabular}{|c|c|c|c|c|c|c|c|c|c|c|}
\hline \multirow[t]{3}{*}{ Life-style factor } & \multicolumn{5}{|c|}{ Heads of a division or a section } & \multicolumn{5}{|c|}{ Foremen } \\
\hline & \multicolumn{2}{|c|}{$\begin{array}{l}\geq 10 \text { workhours } \\
\text { or longer }\end{array}$} & \multicolumn{2}{|c|}{$\leq 9$ workhours } & \multirow[t]{2}{*}{ Pa } & \multicolumn{2}{|c|}{$\begin{array}{c}\geq 10 \text { workhours } \\
\text { or longer }\end{array}$} & \multicolumn{2}{|c|}{$\leq 9$ workhours } & \multirow[t]{2}{*}{$P^{a}$} \\
\hline & N & $\%$ & $N$ & $\%$ & & $\mathbb{N}$ & $\%$ & $N$ & $\%$ & \\
\hline \multicolumn{11}{|c|}{ Sleeping pattern ( $\leq 6$ hours) } \\
\hline $\begin{array}{l}\leq 44 \text { years of age } \\
45-49 \text { years of age } \\
\geq 50 \text { years of age }\end{array}$ & $\begin{array}{l}589 \\
557 \\
341\end{array}$ & $\begin{array}{l}53.2 \\
56.1 \\
57.2\end{array}$ & $\begin{array}{l}133 \\
170 \\
179\end{array}$ & $\begin{array}{l}40.8 \\
42.8 \\
39.8\end{array}$ & $\begin{array}{l}<0.0001 \\
<0.0001 \\
<0.0001\end{array}$ & $\begin{array}{l}326 \\
251 \\
120\end{array}$ & $\begin{array}{l}50.8 \\
47.1 \\
44.6\end{array}$ & $\begin{array}{l}110 \\
188 \\
140\end{array}$ & $\begin{array}{l}29.3 \\
39.2 \\
38.0\end{array}$ & $\begin{array}{c}<0.0001 \\
<0.05 \\
\text { NS }\end{array}$ \\
\hline Total & 1487 & 55.1 & 482 & 41.1 & $<0.0001$ & 697 & 48.3 & 438 & 35.8 & $<0.0001$ \\
\hline \multicolumn{11}{|l|}{ Feeling busy (yes) } \\
\hline $\begin{array}{l}\leq 44 \text { years of age } \\
45-49 \text { years of age } \\
\geq 50 \text { years of age }\end{array}$ & $\begin{array}{l}881 \\
781 \\
454\end{array}$ & $\begin{array}{l}79.5 \\
78.7 \\
76.2\end{array}$ & $\begin{array}{l}125 \\
165 \\
182\end{array}$ & $\begin{array}{l}38.3 \\
41.6 \\
40.4\end{array}$ & $\begin{array}{l}<0.0001 \\
<0.0001 \\
<0.0001\end{array}$ & $\begin{array}{l}477 \\
398 \\
209\end{array}$ & $\begin{array}{l}74.3 \\
74.7 \\
77.7\end{array}$ & $\begin{array}{l}156 \\
215 \\
159\end{array}$ & $\begin{array}{l}41.6 \\
44.9 \\
43.2\end{array}$ & $\begin{array}{l}<0.0001 \\
<0.0001 \\
<0.0001\end{array}$ \\
\hline Total & 2116 & 78.5 & 472 & 40.2 & $<0.0001$ & 1084 & 75.1 & 530 & 43.4 & $<0.0001$ \\
\hline \multicolumn{11}{|c|}{ Regularity of daily life (irregular) } \\
\hline $\begin{array}{l}\leq 44 \text { years of age } \\
45-49 \text { years of age } \\
\geq 50 \text { years of age }\end{array}$ & $\begin{array}{l}551 \\
488 \\
248\end{array}$ & $\begin{array}{l}49.7 \\
49.1 \\
41.6\end{array}$ & $\begin{array}{l}118 \\
142 \\
132\end{array}$ & $\begin{array}{l}36.2 \\
35.8 \\
29.3\end{array}$ & $\begin{array}{l}<0.0001 \\
<0.0001 \\
<0.0001\end{array}$ & $\begin{array}{l}346 \\
259 \\
102\end{array}$ & $\begin{array}{l}53.9 \\
48.6 \\
37.9\end{array}$ & $\begin{array}{l}187 \\
237 \\
126\end{array}$ & $\begin{array}{l}49.9 \\
45.5 \\
34.2\end{array}$ & $\begin{array}{l}\text { NS } \\
\text { NS } \\
\text { NS }\end{array}$ \\
\hline Total & 1287 & 47.7 & 392 & 33.4 & $<0.0001$ & 707 & 49.0 & 550 & 45.0 & $<0.05$ \\
\hline \multicolumn{11}{|c|}{ Regularity of meals (irregular) } \\
\hline $\begin{array}{l}\leq 44 \text { years of age } \\
45-49 \text { years of age } \\
\geq 50 \text { years of age }\end{array}$ & $\begin{array}{l}611 \\
510 \\
248\end{array}$ & $\begin{array}{l}55.1 \\
51.4 \\
41.6\end{array}$ & $\begin{array}{r}120 \\
130 \\
97\end{array}$ & $\begin{array}{l}36.8 \\
32.7 \\
21.6\end{array}$ & $\begin{array}{l}<0.0001 \\
<0.0001 \\
<0.0001\end{array}$ & $\begin{array}{r}340 \\
239 \\
81\end{array}$ & $\begin{array}{l}53.0 \\
44.8 \\
30.1\end{array}$ & $\begin{array}{l}171 \\
205 \\
112\end{array}$ & $\begin{array}{l}45.6 \\
42.8 \\
30.4\end{array}$ & $\begin{array}{c}<0.05 \\
\text { NS } \\
\text { NS }\end{array}$ \\
\hline Total & 1369 & 51.5 & 347 & 31.0 & $<0.0001$ & 660 & 45.7 & 488 & 39.9 & $<0.005$ \\
\hline \multicolumn{11}{|l|}{$\begin{array}{l}\text { Physical condition } \\
\text { during the last six } \\
\text { months (worse) }\end{array}$} \\
\hline $\begin{array}{l}\leq 44 \text { years of age } \\
45-49 \text { years of age } \\
\geq 50 \text { years of age }\end{array}$ & $\begin{array}{r}167 \\
137 \\
65\end{array}$ & $\begin{array}{l}15.1 \\
13.8 \\
10.9\end{array}$ & $\begin{array}{l}30 \\
41 \\
41\end{array}$ & $\begin{array}{r}9.2 \\
10.3 \\
9.1\end{array}$ & $\begin{array}{r}<0.01 \\
\text { NS } \\
\text { NS }\end{array}$ & $\begin{array}{r}129 \\
112 \\
42\end{array}$ & $\begin{array}{l}20.1 \\
21.0 \\
15.6\end{array}$ & $\begin{array}{l}52 \\
55 \\
32\end{array}$ & $\begin{array}{r}13.9 \\
11.5 \\
8.7\end{array}$ & $\begin{array}{l}<0.05 \\
<0.0001 \\
<0.01\end{array}$ \\
\hline Total & 369 & 13.9 & 112 & 9.6 & NS & 283 & 19.6 & 139 & 11.4 & $<0.0001$ \\
\hline
\end{tabular}

a Chi-square test, $\mathrm{NS}=$ not significant.

Exercise. In the long workhour group, the frequency of exercise was generally one time per week or less at all the age levels. A significant difference was observed for the workhours and exercise of the divisional or sectional heads in the age group of $\leq 44$ years and for all the age groups combined and for foremen in the age groups of $\leq 44$ years, and $45-49$ years and for all the age groups combined.

Degree of obesity, whether breakfast is eaten every morning or not, eating between meals, and salt intake. No significant relationship was observed between workhours and the degree of obesity, whether breakfast was eaten or not every morning, eating between meals, and salt intake for the divisional or sectional heads or the foremen.

Intake of black tea and coffee. The percentage of individuals who frequently drank black tea or coffee was higher in the long workhour group in all the age groups. Significant differences were observed for both the divisional or sectional heads and the foremen in the age groups of $\leq 44$ years, $45-49$ years, and all the age groups combined.
Nutritional balance. The percentage of persons who paid little attention to nutritional balance was higher in the long workhour group at all the age levels. The difference was significant for the divisional or sectional heads when all the age groups were combined.

Hobbies and business. The percentage of persons who had no hobbies was high in the long workhour group at each age level, but the difference was not significant. A significantly higher percentage of both the divisional or sectional heads and the foremen felt busy in the long workhour group at each age level and when all the age levels were combined.

Regularity of daily life and meals. The percentage of persons who had an irregular daily life and irregular meals was higher in the long workhour group at each age level. Significant differences were observed in the regularity of both the daily life and the meals of the divisional or sectional heads at each age level and when all the age groups were combined and in the regularity of life for the foremen when all the age groups were combined and in the regularity of meals for the foremen aged $\leq 44$ years and when all the age groups were combined. 
Physical condition during the last six months. The percentage of persons who experienced deterioration in their physical condition was higher in the long workhour group at each age level. Significant differences were observed for the divisional or sectional heads aged $\leq 44$ years and the foremen of each age group and when all the age groups were combined.

\section{Relationship between workhours and subjective stress}

Figure 3 shows the results of the oneway analysis of variance concerning the relationship between workhours and stress separately for the divisional or sectional heads and the foremen. For both the divisional or sectional heads and the foremen, the subjective stress level was significantly higher as the workhours increased. A similar relationship was observed at each age level. Table 2 shows the odds ratios of the appearance of the highstress group calculated in consideration of the effect of age. The percentage of divisional or sectional heads for whom the stress level was high was 2.51 times higher in

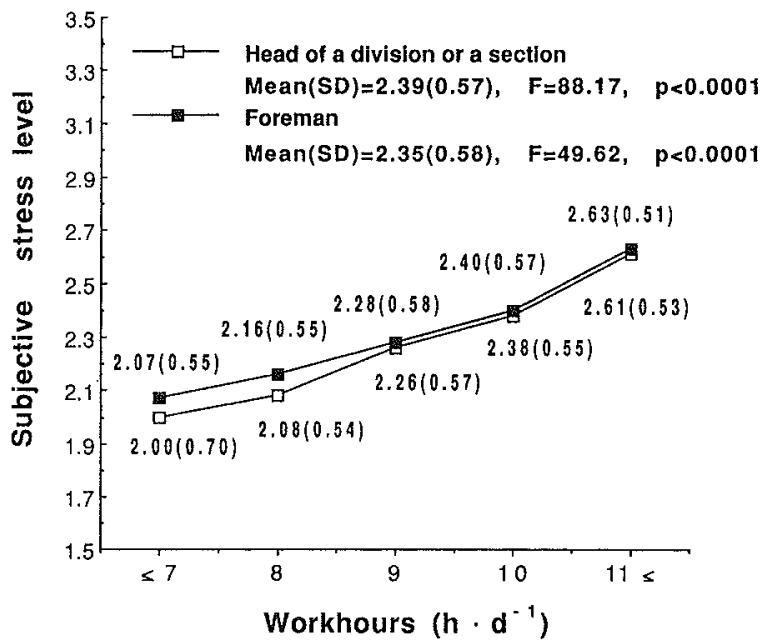

Figure 3. Relationsip of the number of workhours to the score of subjective stress for 3870 heads of a division or section and 2666 foremen (oneway analysis of variance). Note: For both the divisional or sectional heads and foremen, the subjective stress level was significantly higher as the workhours increased (Scheffes's test). the long workhour group than in the short workhour group. In addition, 2.35 times more foremen felt a high level of stress in the long workhour group.

\section{Relationship between workhours and subjective quality of life}

Figure 4 shows the results of the oneway analysis of variance of the relationship between workhours and subjective quality of life. There was a significant difference $(\mathrm{P}<0.01)$ concerning quality of life between the divisional and sectional heads and the foremen. According to workhours, the subjective quality of life was lower for the foremen than for the divisional or sectional heads, and it was the lowest for both the divisional or sectional heads and the foremen when the workhours were $\geq 11 \mathrm{~h}$. Similar results were obtained also for each age group. Table 3 shows the odds ratios of the appearance of low quality-of-life individuals calculated with respect to the effect of age. For the divisional or sectional heads, the frequency of the low quality-of-life group was 1.17 times

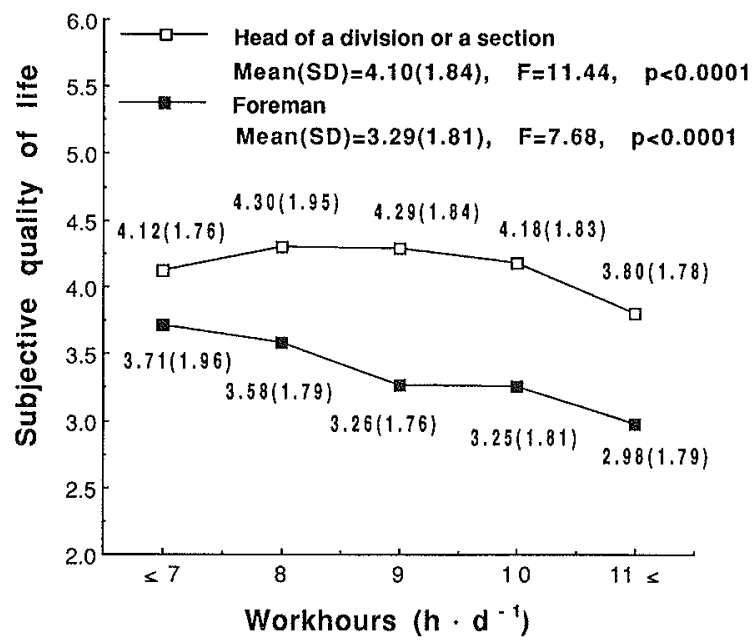

Figure 4. Relationship of the number of workhours to the score of subjective quality of life of 3870 heads of a division or section and 2666 foremen (oneway analysis of variance). Note: It was significantly the lowest for both the divisional or sectional heads and the foremen when the workhours were $\geq 11$ hours (Scheffe's test).

Table 2. Prevalence of high subjective stress according to the number of hours worked by the heads of a division or a section $(\mathrm{N}=3870)$ and the foremen $(\mathrm{N}=2666){ }^{\text {a }}$

\begin{tabular}{|c|c|c|c|c|c|c|c|c|}
\hline \multirow[t]{2}{*}{ Workhours } & \multicolumn{4}{|c|}{ Heads of a division or a section } & \multicolumn{4}{|c|}{ Foremen } \\
\hline & $N$ & $\begin{array}{c}\text { Prevalence } \\
(\%)\end{array}$ & $O R^{b}$ & $95 \% \mathrm{Cl}^{\mathrm{c}}$ & $N$ & $\begin{array}{c}\text { Prevalence } \\
(\%)\end{array}$ & $O R^{b}$ & $95 \% \mathrm{Cl}$ \\
\hline$\geq 10$ hours & 2697 & 50.8 & 2.51 & $017 \cdot 300+x+t$ & 1444 & 58.0 & 2.35 & 001 O Z \\
\hline$\leq 9$ hours & 1173 & 28.6 & $\cdot$ & $2.17-2.90^{0 * * *}$ & 1222 & 30.0 & . & $2.01-2.75^{\mathrm{b**}}$ \\
\hline
\end{tabular}

a The subjects were classified as reporting $\geq 10$ workhours and $\leq 9$ workhours. Adjustment for age, number of years in managerial positions, number of subordinates, and type of division.

- Calculated as the odds of high subjective stress among the intermediate managers with $\geq 10$ workhours divided by the odds of high subjective stress among the intermediate managers with $\leq 9$ workhours.

- Approximate $95 \%$ confidence interval for the odds ratio $(O R)$ based on a transformation of approximate limits for the log of the $O R$.

$* * * \mathrm{P}<0.001$. 
Table 3. Prevalence of perceived low level of quality of life ( 3 or less) according to the number of hours worked by the heads of a division or a section $(\mathrm{N}=3870)$ and the foremen $(\mathrm{N}=2666)$. $^{\mathrm{a}}$

\begin{tabular}{|c|c|c|c|c|c|c|c|c|}
\hline \multirow[t]{2}{*}{ Workhours } & \multicolumn{4}{|c|}{ Heads of a division or a section } & \multicolumn{4}{|c|}{ Foremen } \\
\hline & $\mathrm{N}$ & $\begin{array}{c}\text { Prevalence } \\
(\%)\end{array}$ & $\mathrm{OR}^{0}$ & $95 \% \mathrm{Cl}^{\mathrm{c}}$ & N & $\begin{array}{c}\text { Prevalence } \\
(\%)\end{array}$ & $O R^{b}$ & $95 \% \mathrm{Cl}^{\mathrm{C}}$ \\
\hline $\begin{array}{l}\geq 10 \text { hours } \\
\leq 9 \text { hours }\end{array}$ & $\begin{array}{l}2697 \\
1173\end{array}$ & $\begin{array}{l}37.7 \\
32.7\end{array}$ & 1.17 & $1.02-1.36^{c *}$ & $\begin{array}{l}1444 \\
1222\end{array}$ & $\begin{array}{l}58.0 \\
51.4\end{array}$ & 1.26 & $1.08-1.46^{b^{* *}}$ \\
\hline
\end{tabular}

a The subjects were classified as reporting $\geq 10$ workhours and $\leq 9$ workhours. Adjustment was made for age, number of years in managerial positions, number of subordinates, and type of division.

b Calculated as the odds of a perceived low level of quality of life among the intermediate managers with $\geq 10$ workhours divided by the odds of a perceived low level of quality of life among the intermediate managers with $\leq 9$ workhours.

c Approximate $95 \%$ confidence interval for the odds ratio (OR) based on a transformation of approximate limits for the log of the $0 \mathrm{R}$

$* P<0.05 * * P<0.01$.

higher in the long workhour group than in the short one. For the foremen, the difference was 1.26 times higher.

\section{Discussion}

Our study indicated that the majority of managers at the intermediate level work relatively longer. From the time of our investigation, statistics from the Japanese government (4) have indicated that the annual net workhours of the total population of workers have been decreasing. However, some discrepancies may exist between the figure in the statistics and the actual workhours, since voluntarily unpaid overtime work might not be included in the statistical figure. Therefore the actual workhour conditions of the intermediate management class might not have changed significantly from the time of our investigation. In this study, we evaluated the effects of long workhours on health from the following two approaches. First, we could not evaluate the long-term effects on health because our study was a cross-sectional investigation. Accordingly, we assessed the effects of long workhours on life-style. Secondly, the direct effects of long workhours on mental health were evaluated by subjective stress and subjective quality of life.

Concerning the effects of long workhours on lifestyle, the men who generally worked longer tended to have an unhealthy life-style as compared with those who worked relatively shorter hours. Of the seven health practices recommended by Berkman \& Breslow (15), sleep time was the most significantly influenced by long workhours. The present findings that people felt busy and their life and diets tended to be irregular when the workhours were longer suggest that the length and distribution of workhours determine the framework of worklife and that workhours regulate the cycle of daily living. Concerning other aspects of life-style, workhours were significantly related to the frequency of black tea or coffee intake. The increased chances of drinking beverages of taste in long workhours may be a factor in the high incidence of peptic ulcer among the Japanese. The fact that long workhours were closely related to many aspects of life-style, including the regularity of sleep, daily life, and meals, suggests that the shortening of daily workhours may be more effective for improving life-style than increasing the number of regular weekly holidays or paid holidays.

It was a remarkable finding that the frequency of high stress was 2.51 times higher for the divisional or sectional heads and 2.35 times higher for the foremen among those who worked long hours than among those who worked relatively shorter hours. The frequency of low quality of life was 1.17 times higher for the divisional or sectional heads and 1.26 times higher for the foremen among those who worked long hours than among those who worked relatively short hours. We introduced the evaluation of quality of life because the goal of health management in Japan has shifted from decreasing the rate of unhealthy conditions and stress to realizing greater satisfaction with both work and daily life. The finding that the correlation between quality of life and long workhours was lower than that between stress and long workhours suggests that intermediate management in Japan generally accepts long workhours to some extent in the Japanese employment style characterized by lifelong employment and the seniority of payment, even though they suffer severe stress from long workhours.

Some reports on the relationship between long workhours because of excessive overtime work and health among white-collar workers have been published. In Japan, Uehata (1) showed that, of the occupational accident counseling cases, $70.1 \%$ of overfatigue deaths due to stroke or cardiac disease was caused by long workhours. Only a few studies have evaluated the effects of long workhours on the health of intermediate managers. Cooper and his colleagues $(8,10)$ found a strong relationship between long workhours and mental health as a source of stress among supervisory police officers and tax officers (higher grade). Recently, Hurrell \& Lindström (13) reported that physical symptoms such as headache and heart symptoms were caused by long workhours among male managers in Finland. Our results agreed well with these findings. 
The following methodological weaknesses should be considered when our results are analyzed. First, stress may not be caused solely by long workhours, rather there may be another cause. In the present study, we did not consider factors such as personality as confounders; we included only age and type of division. The effects of other factors should be considered in future studies. Second, further evaluations should be done on the validity and reliability of the questionnaire on subjective stress and subjective quality of life. Finally, the indirect effects of long workhours on health through life-style, as illustrated in the model in figure 1 should be clarified by cohort studies.

Workhours are difficult to adjust for on the individual level and therefore measures must be taken on an organizational basis. There are theories suggesting that Japanese social and business organizations have characteristic vertical structures (24) and that the Japanese managerial system characterized by communityism and groupism is prevalent in the workplace (25). The results of our study suggest that it will be difficult for the organization to become a comfortable place to work unless intermediate-level managers, who are key persons in the organization, shorten their workhours and correct their life-style for better mental life and quality of life. Our results underlined the importance and urgency of shortening the workhours of these managers to improve both mental and physical health in the workplace.

\section{Acknowledgments}

We are grateful to Dr Keizo Kohno for his valuable suggestions.

The study was supported by a grant-in-aid for special research from the Foundation for Promotion of Industrial Medicine of Japan.

\section{References}

1. Uehata T. Long working hours and occupational stress-related cardiovascular attacks among middle-aged workers in Japan. J Hum Ergol (Tokyo) 1991;20:147—53.

2. Ministry of Labor. The age of the reduction of working hours and the restructuring [in Japanese]. Tokyo: Ministry of Labor, 1992.

3. Economic Planning Agency. The economic white paper for 1993 [in Japanese]. Tokyo: Finance Ministry, 1993.

4. Ministry of Labor. The labor white paper for 1994 [in Japanese]. Tokyo: Ministry of Labor, 1994.

5. Harrington JM. Working long hours and health. Br Med J 1994;308:1581-2.
6. Buell P, Breslow L. Mortality from coronary heart disease in California men who work long hours. J Chronic Dis 1960;11: $615-26$.

7. Russek HI, Zohnman BL. Relative significance of heredity, diet and occupational stress in CHD of young adults. Am J Med Sci 1958;235:266-75.

8. Cooper CL, Davidson MJ, Robinson P. Stress in the police service. J Occup Med 1982;24:30—6.

9. Richardsen AM, Burke RJ. Occupational stress and job satisfaction among physicians: sex differences. Soc Sci Med 1991; $33: 1179-87$

10. Cooper CL, Roden J. Mental health and satisfaction among tax officers. Soc Sci Med 1985;21:747-51.

11. McCall TB. The impact of long working hours on resident physicians. New Engl J Med 1988;318:775-8.

12. Ono Y, Watanabe S, Kaneko S, Matsumoto K, Miyako M. Working hours and fatigue of Japanese flight attendants. J Hum Ergol 1991;20:155-64.

13. Hurrel JJ, Lindström K. Comparison of job demands, control and psychosomatic complaints at different career stages of managers in Finland and the United States. Scand $\mathbf{J}$ Work Environ Health 1992;18 suppl 2:11-13.

14. Watanabe S, Torii J, Shinkai S, Watanabe T. Relationships between health status and working conditions and personalities among VDT workers. Environ Res 1993;61:258-65.

15. Berkman LF, Breslow L. Health and ways of living: the Alameda County study. New York (NY): Oxford University Press, 1983.

16. Morimoto K, Kaneko T, Iijima K, Koizumi A. Health situation and chromosome alterations: sister chromatid exchange frequency in lymphocyte from passive smokers and patients with hereditary disease. In: Tice R, Hollaender A, Lambert B, Morimoto K, editors. Sister chromatid exchanges: genetic toxicology and human studies. New York (NY): Plenum 1984:801-12.

17. Frederick T, Frerichs RR, Clark VA. Personal health habits and symptoms of depression at the community level. Prey Med 1988;17:173-82.

18. Simonsick EM. Personal habits and mental health in a national probability sample. Am J Prev Med 1991;7:425-37.

19. Morimoto K. Life-style and genetic factors that determine the susceptibility to production of chromosome damage. In: Obe G, Natarajan AT, editors. Chromosomal aberrations: basic and applied aspects. Berlin: Springer-Verlag, 1990:287-301.

20. Kusaka Y, Kondou H, Morimoto K. Healthy lifestyles and associated with higher natural killer cell activity. Prev Med 1992;21:602-15.

21. Maruyama S, Sato H, Morimoto K. Relationships between working-life satisfaction, health practices and primary symptoms/problems. Jpn J Hyg 1991;45:1082--94.

22. Ezoe S, Morimoto K. Behavioral lifestyle and mental health status of Japanese factory workers. Prev Med 1994;23:98 105.

23. Ogiwara M. Quality of life of the Japanese [in Japanese]. Tokyo: Shinseido, 1987.

24. Nakane C. Human relations in vertical structures [in Japanese]. Tokyo: Koudansha, 1967.

25. Tsuda M. The logic of the Japanese managerial system [in Japanese]. Tokyo: Chuoukeizaisha, 1977.

Received for publication: 11 May 1995 